\title{
Foreign Aid and Economic Growth in Vietnam: Empirical Study and Policy Implications
}

\author{
Nguyen Hoang Quy ${ }^{1}$ \\ ${ }^{1}$ National Academy of Public Administration, Hanoi, Vietnam \\ Correspondence: Ph.D. Nguyen Hoang Quy, National Academy of Public Administration, 77 Nguyen Chi Thanh, \\ Dong Da district, Hanoi, Vietnam. Tel: 84-43-764-3219. E-mail: nghoangquy@yahoo.com
}

Received: October 6, 2016 Accepted: October 24, 2016 Online Published: October 30, 2016

doi:10.5539/par.v5n2p53

URL: http://dx.doi.org/10.5539/par.v5n2p53

\begin{abstract}
This paper studies the impact of foreign aid on Vietnam economic growth. By analyzing Vietnam statistical data, the research results show a negative relationship between foreign aid and economic growth of Vietnam. The main reason may be due to wrong and ineffective usage of this aids, and also corruption in the country. On these basis, we propose some recommendations for improving the performance of aid usage by strictly managing and reasonably allocating aid fund. Accordingly, Vietnam Government should improve the State's management capacity by implementing decentralized administration in a clear and transparent manner; by simplifying procedures; by improving aid-funded project appraisal; and by ensuring an independence of foreign aids.
\end{abstract}

Keywords: foreign aid, ODA fund, economic growth, policy, Vietnam

\section{Introduction}

Currently, researchers discuss continuously the two opposite opinions about impacts of foreign aid on economic growth of recipient country. Bauer (1972) stated that foreign aid is a process in which the poor in rich countries aid the rich in poor countries; and it does not have any impact on economic growth. The opposite opinions oppose by saying that foreign aid is an important way to boost economic development for eliminating hunger and reducing poverty in less developed countries over the world. According to Sachs (2005), foreign aid does not always lead to optimal results, it still plays an important role in reducing poverty and assisting in growth in many countries.

As a developing country, Vietnam is actually in the industrialization and modernization process with important capital need. Every year, Vietnam receives foreign aids from other countries over the world in various forms for its economic development. The impacts of foreign aid on economic and infrastructure development of the country seems significant in recent years as stated by Government. Nevertheless, Vietnam has to sacrifice several economic benefits for aid-giving countries; and also serious corruptions are identified in development projects relating to foreign aids form Japan, China and Australia.

In this context, we focus on the subject of "Foreign aid and economic growth in Vietnam: empirical study and policy implications". The primary objectives consist in studying the impacts of foreign aid on economic growth in Vietnam, and in proposing relevant recommendations for using effectively foreign aid in favor of Vietnam economic growth in the context of globalization.

\section{Theoretical Framework}

\subsection{Concept and Characteristics of Foreign Aid}

According to the Development Assistance Committee (1972), foreign aid, also known as foreign assistance, is a source of funds given or offered by foreign governments, or enterprise or individuals. There are many forms of aid such as urgent humanitarian assistance, food assistance, military assistance, capital flow assistance for development... These capital sources play a very important role for developing countries in their economic development.

Foreign aids have some characteristics, including: (i) Foreign aid involves a transfer of financial resources or commodities or technical advice and training; donors do not directly manage aid-funded project, however, they can indirectly take part in the project as contractors or support experts. Aid-funded projects are established 
basing on the donors' agreement. (ii) Foreign aid includes non-refundable and concessional one. However, ineffective aid management and usage may increase debt burden in the future. (iii) Recipient country has to fully meet a certain number of requirements. (iv) Foreign aid is mainly used to develop infrastructure such as transportation, education, medicine ... (v) Donors are multilateral aid organizations (including: The United Nations agencies, the European Union, International Monetary Fund, World Bank, Asian Development Bank ...) and bilateral aid organizations. (vi) Foreign aid depends on political connection, and opinion of aid-giving countries and recipient countries. (vii) There is a stiff competition in attracting foreign aid resources among countries (Ngo Thang Loi, 2013).

There are in general three categories of foreign aid (Dalgaard et al., 2004): (i) Official development assistance ODA including assistance from governments of aid-giving countries for low and medium income countries; (ii) Official assistance - OA is the assistance provided by the governments of aid-giving countries for richer countries and with income per capita higher of about USD 9,000; (iii) Private voluntary assistance including assistance from governmental organizations, religious groups, charity organizations, funds and private enterprises.

\subsection{Relationship between Foreign Aid and Economic Growth}

In the literature, we identified two models frequently used for analyzing the relationship between aid and economic growth. The first model is named "Two Gap model". This one is a theoretical framework of foreign aid that compares the gaps between saving and exchange rate to determine what are constraints of an economy. According to McMillan (2011), the Two Gap model determines the impacts of the two factors on growth. The first one is the relationship between investment and growth of a country, in which growth rate is assumed to depend on investment level. The second one is the relationship between saving and growth, in which saving is assumed to be an important factor in expanding investment and influence economic growth. This model allows determining the necessary investment level in order to achieve a desired rate of economic growth. Deficiency occur when the rate of investment exceeds the domestic saving rate; and such deficiencies will be financed by borrowed funds (debts) from abroad.

Nevertheless, the Two Gap model faced some criticisms. As the Two Gap model assumes that investment is the only factor affecting economic growth beside the other factors (including: education, research \& development ...). Harms and Lutz (2004) pointed out that not every country is ready to receive aid from others. Aid is not only for the purpose the recipient countries will use it for economic development but also to use part of it for consumption (Government spending...). They also indicated that being ready to receive foreign aid is synonym to encourage corruption. Face to criticisms, some researches defended by assuming that for a flexible and transparent economy, most recipient countries would use it for the purpose of developing economy by reducing hunger and poverty.

The second model of Poverty Trap model was initially developed by Nelson (1956). This model assumes that economic growth is not prevented by hunger and poverty, but by many factors such as low productive capacity, high population growth, low savings ratio... For whatever causes, poverty is considered as a compromise to receive aid from foreign countries to stimulate economic growth. The Poverty Trap model is considered as a theoretical framework for the relationship between foreign aid and economic growth.

In general, although there are incentives of interest (0.75-2\%/year), grace period (8-10 years) and repayment schedule (30-40 years), recipient country has to accept a number of relatively hard requirements relating to politics, support at international fora, aid-funded project effectiveness, capital transfer procedure ... Thus, the recipient country needs to consider foreign aid resources by evaluating financial terms for avoiding waste of resources and debt burden in the future. Beside the factors relating to aid-funded project, the recipient country needs to concentrate on foreign aid agreements for ensuring country benefits (Chan Luan, 2016; McMillan, 2011).

\subsection{Empirical Studies of the Relationship between Foreign Aid and Economic Growth}

During the 1950s, several debates occurred about the role of foreign aid in economic growth. Researchers such as Friedman (1958) and Bauer (1972) called for ending foreign aid by assuming that this was not a pressing need for economic growth in a country. They stated that foreign aid resulted in corruption and obstruction to the economic development. Particularly, Bauer (1972) noted that economic aid did not assist in economic growth in the private sector but encouraged growth in the State economic sectors by causing anhidrotic impact, reducing growth and hampering development.

Empirically, Griffin and Enos (1970) published the results of their practical surveys in 27 countries by indicating 
a negative relationship between foreign aid and economic growth of a country. Kanbur (2000) agreed that foreign aid do not have impacts on economic growth. They showed that foreign aids are usually overused by host governments; it does not exist any impact on growth due to corruption, weaknesses in management, pressures from aid-giving countries to recipient countries... Also, Boone (1996) found that foreign aids do not influence economic growth of recipient countries for two reasons: (i) poverty and hunger are not due to lack of capital and (ii) it is not optimal for politicians to adjust distortionary policies when they receive aid flows. Mosley (1980) acknowledged the success of numerous aid projects from private individuals and organizations. He still, however, remarked that successful projects could not compensate for the overall negative impacts of aid on growth and development of recipient countries.

In contrast, several researches found positive impacts of foreign aids on economic growth of recipient countries. McMillan (2011) believed that aids would contribute to economic growth by increasing savings and financing investments; by increasing productivity, particularly in health and education programs. They also further considered technology transfer from rich countries to poor countries as positive impacts. Hansen and Tarp (2001) and Dalgaard et al. (2004) stated that although foreign aid does not have the absolute relationship with growth, it still proves the higher the aid flows are the quicker they speed up economic growth of recipient countries. Stiglitz (2002) augmented that foreign aid, which may fail in some cases, can certainly stimulate economic growth in certain recipient countries.

In summary, empirical studies are contradictory on the relationship between foreign aid and economic growth of recipient countries.

\section{Methodology}

The research object focuses on impact of foreign aid on economic growth of recipient country. Precisely, we assess the role and performance of Official Development Assistance (ODA) by analyzing its impacts on GDP growth of Vietnam. Statistical data relating ODA and GDP growth of Vietnam between 1993 and 2015 are collected from the Statistical Yearbook of Vietnam. Although the data were secondary; they possess a high level of validity as collected from official governmental source.

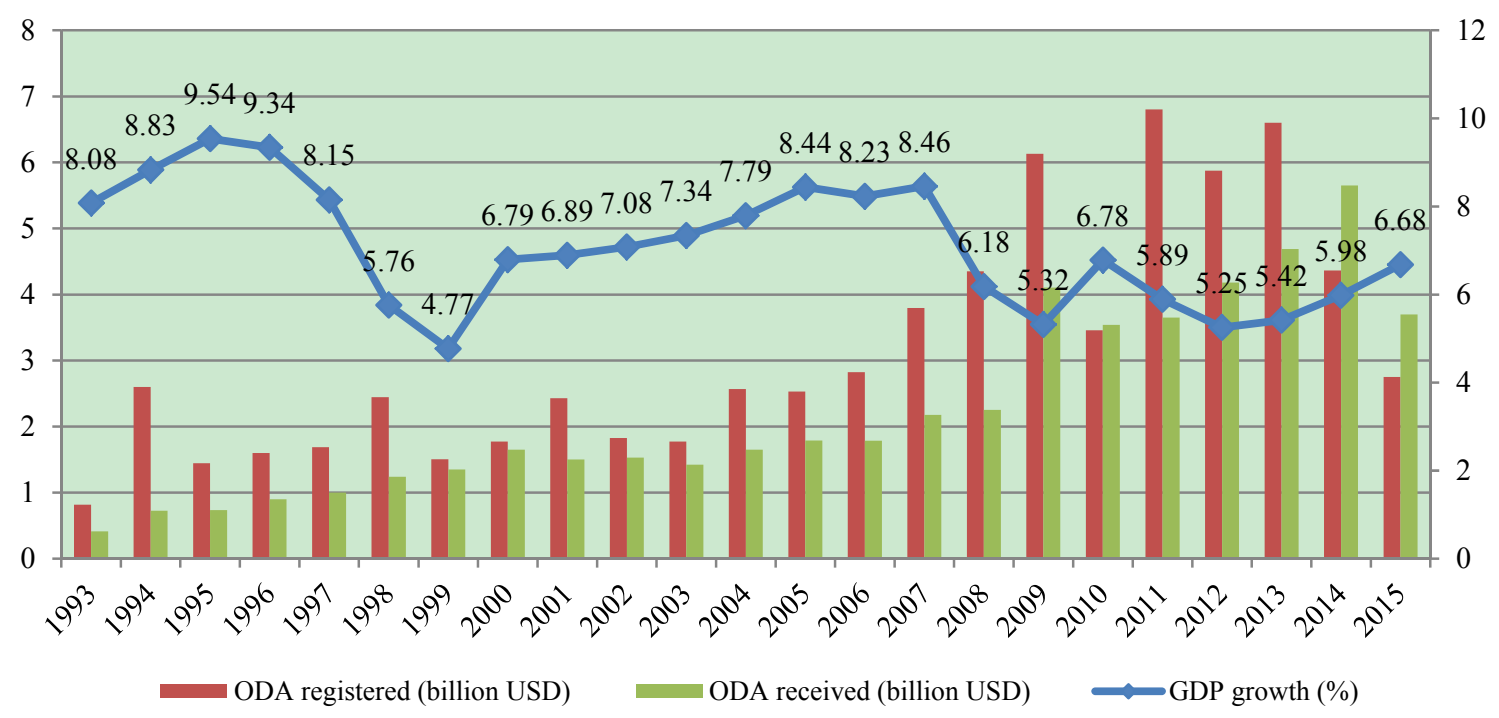

Figure. ODA and GDP growth of Vietnam in the period of 1993-2015

Source: Statistical Yearbook of Vietnam (1993-2015)

We can see that foreign aids received by Vietnam were increasing during the period 1993 - 2015. Initially, the scale of ODA to Vietnam was still low (signature of USD 816 million aid, USD 413 million disbursement). This increased gradually and reached the highest amount in 2011 (signature of USD 6,803 million and USD 3,650 million disbursement). The period after the financial crisis 2008 saw a remarkable increase of ODA in Vietnam; the level of disbursement usually accounts for around $50 \%-70 \%$ of the aid budgets as committed by aid-giving countries. 
In order to assessing the relationship between ODA and GDP growth, we employ Pearson's correlation coefficient. Since we analyze two correlation coefficients between two types of ODA (the ones registered and received) and GDP growth of Vietnam.

\section{Research results}

The research findings on the correlation between ODA and GDP growth of Vietnam are presented as following:

Table 1. Analytical result of Pearson correlation coefficients

\begin{tabular}{llrrr}
\hline & & GDP growth & ODA_reg & ODAD_rec \\
\hline GDP growth (\%) & Pearson Correlation & 1 & $-0.578^{* *}$ & $-0.633^{* *}$ \\
& Sig. (2-tailed) & & 0.004 & 0.001 \\
& $\mathrm{~N}$ & 23 & 23 & 23 \\
\hline ODA_reg & Pearson Correlation & $-0.578^{* *}$ & 1 & $0.820^{* *}$ \\
& Sig. (2-tailed) & 0.004 & & 0.000 \\
& $\mathrm{~N}$ & 23 & 23 & 23 \\
\hline ODAD_rec & Pearson Correlation & $-0.633^{* *}$ & $0.820^{* *}$ & 1 \\
& Sig. (2-tailed) & 0.001 & 0.000 & \\
& $\mathrm{~N}$ & 23 & 23 & 23 \\
\hline
\end{tabular}

**. Correlation is significant at the 0.01 level (2-tailed).

Our results showed that the Pearson's correlation coefficient between GDP growth and ODA registered was -0.578 ; the one between GDP growth and ODA received was -0.633 ; both were significant at confidence level of $95 \%$. These negative relationships imply that the more strongly Vietnam receive ODA, the more slowly its GDP grows; and vice versa.

According to our analysis, these negative relationships between ODA and GDP growth in Vietnam, particularly in recent years, may due to some main following reasons: Firstly, as 2008 was the onset year of the world economic crisis, Vietnam was more or less under the negative impacts of this crisis. In such a crisis, growth principles are not usually correct, although very high ODA flows can come from other countries, yet, enormous capital may probably not result in economic growth during a difficult period.

Secondly, in the early years or renovation, ODA flows were chiefly used in the country's process of reconstruction, allocated for investment in infrastructure (transport, power, water supply and drainage, telecom, education, healthcare...). With ODA flows, Vietnam has made some significant achievements; average income per capita has unceasingly been being growing. In recent time, however, ODA flows have become saturated and it is getting more and more difficult to have access to these flows. There is no reason for Vietnam to receive free aid flows from developed countries. According to Chan Luan (2016), ODA are not a free lunch. The aid-giving countries will certainly receive economic and political benefits. For example, in order to receive ODA from Japan, Vietnam has to implement tax exemptions or have a number of financial transactions with Japanese currently doing business in the Vietnamese market for a certain period, or to concede the right to trade in some types of commodities in Vietnam... Thus, part of the growth benefits is divided among the rich countries looking for profits in developing countries.

Thirdly, as Vietnam is a developing country, errors in activities of managing and dividing funds among localities are unavoidable. For the time being, we are allocating the flows in a far and wide spreading manner, without focusing on the highly profitable lines of business. Fund resources are being spread far and wide from Mong Cai to $\mathrm{Ca} \mathrm{Mau}$, without concentrating on mainly on provinces, cities with high potential for development. Moreover, the mechanism for distributing ODA flows among locality at present is chiefly under the mode of allocating. The 'asking-giving' mechanism or practice is still popular and not much change has been made. Funds are distributed by the Central Government to localities but the management and use such resources are inefficient. Works or projects that use assistance flows often fall behind schedule, therefore, we have to continue providing funds to finish them. A project, if finished on schedule, will bring numerous benefits, but, if delays in implementing, will probably consume more additional money from the Government due to impact of slippage in 
prices, meanwhile, the long payback period of the project leads to the fact that many projects upon completion reveal their weaknesses, causing the State's loss of thousands of billion dong (Chan Luan, 2016).

Furthermore, the ever-increasing tendency of aid results in the increase in the Government spending, while Vietnam has many years overspending the budget. The Government cannot increase tax to compensate for that, thus leading to impacts on economic growth. In addition, the corollary of poor management will give rise to the ever-growing corruption and wastage. Part of ODA will not be used for the right purposes, thereby failing to demonstrate its importance to economic growth (Ngo Thang Loi, 2013).

\section{Policy Implications}

On the basis of research findings of the negative impacts of foreign aids on economic growth in Vietnam, we propose some relevant recommendation for managing and using foreign aids reasonably by efficiently in recipient countries, specifically:

Firstly, the commitment of receiving aid should be changed in terms of contents and conditions in order to avoid sacrificing the national interests while Vietnam's investment capacity is still being weak. There should be very professional consultants to guarantee that Vietnam will not be at a disadvantage in implementing its commitments with aid-givers. For the fund resources that require disadvantages commitments, Vietnam should bravely decline so as to enhance its proactiveness towards foreign organizations.

Secondly, Vietnam should have clear and efficient policies of managing foreign aids. The 'asking-giving' mechanism between the State and localities should be repealed and replaced with the policy on borrowing and sub-lending, from that to encourage localities to use the aid flows in an effective manner. There should be a clear distinction between responsibilities at different levels, an increase in fund management efficiency (e.g. clear decentralized administration between the Central Government and local authorities, avoidance of overlapping in the management model resulting in delay in implementing aid-receiving projects and reduction in running, managing activities). Sectors, localities applying for aid to use should be responsible for calculating exactly the performance and defining their full debt service obligations, and always putting the national interest above all. For projects calling for enormous fund resources, specific periods of paying debt service obligations should be defined, profitability should be calculated in detail to ensure investment performance and with plan for paying foreign debts.

Thirdly, aid flows for Vietnam are not infinite. Therefore, Vietnam should be oriented towards using aid in a scientific, reasonable manner so as to bring into full play the positive impacts of aid on the economy. Besides, the Government should also give priority to the use of fund resources towards continuing to build essential infrastructure, to improve public services, to develop human resources and skills, to improve social security network, to sustain green growth, to cope with climate change, to reduce disaster risks, to develop policy-planning skills, and enhancing managing capacity of the State.

Fourthly, Vietnam state should simplify and improve project appraisal as well as strengthen the monitoring and supervision of aid-funded projects. Vietnam state should take measures to improve the system for assessing, managing information about the projects which has been and are going to be granted aid, to ensure that the projects will strictly comply with the initial commitment, avoiding losses and wastage. In addition, managers' capacity should also be enhanced to be able to monitor, assess and oversee the projects in an effective manner. The participation of the community in supervising project activities should also be encouraged to ensure law observation. There should be mechanism for encouraging, creating favourable conditions for the participation of the people so as to help enhance efficiency of capital utilization.

Fifthly, at present, Vietnam has a wide range of documents available on managing and using aid flows. Such documents, however, are still characterized by their overlapping; failing to give an insight into the issues that Vietnam is confronted with when aid flows are not used in an effective manner. Therefore, there should be some legal document to provide guidance, gathering sufficient information to create a uniform legal corridor to help State administration bodies to regulate efficiently activities of foreign borrowing at interest.

Sixthly, Vietnam should be proactive in reciprocal capital for avoiding the total dependence on foreign aid flows which results in prolonged project implementation and inefficiency. Proactiveness in fund resources will help improve the sense of thrift in Government spending and avoid unnecessary wastage.

\section{Concluding Remarks}

By analyzing statistic data of ODA and GDP growth of Vietnam during 23 years from 1993 to 2015, we provided strong theoretical support for the impact of foreign aids on Vietnam economic growth. We can see that between 1993 and 2006, aid had fairly positive impacts on Vietnam economy; however, since 2008 up to now, the relation 
diagram between these two factors has not been following any certain principle, even in inverse proportion to each other. Our analysis of Pearson's correlation coefficients between ODA and GDP growth show that foreign aid and economic growth in Vietnam have a negative relationship.

On the basis of findings, we proposed a number of recommendations for improving the ability to get access to and use foreign aid in an effective manner in the forthcoming period. Accordingly, Vietnam Government should improve the State's management capacity by implementing decentralized administration in a clear and transparent manner; by simplifying procedures; by improving aid-funded project appraisal; and by ensuring an independence of foreign aids.

\section{References}

Bauer, P. (1972). Dissent on development. Cambridge: Harvard University Press.

Boone, P. (1996). Politics and the impactiveness of foreign aid. European Economic Review, (40), 289-329.

Dalgaard, C., Hansen, H., \& Tarp, F. (2004). On the empirics of foreign aid and growth. Economic Journal, 114(496), 191-216. http://dx.doi.org/10.1111/j.1468-0297.2004.00219.x

Friedman, M. (1958). Foreign Economic Aid. Yale Review, 47(4), 501-516.

Griffin, K., \& Enos, J. (1970). Foreign assistance, objectives and consequences. Economic Development and Cultural Change, 18(3). http://dx.doi.org/10.1086/450435

Hansen, H., \& Tarp, F. (2001). Aid and growth regressions. Journal of Development Economics, 64, 547-570. http://dx.doi.org/10.1016/S0304-3878(00)00150-4

Harms, P., \& Lutz, M. (2004). The macroeconomic impacts of foreign aid. Discussion Paper no. 2004-11, Department of Economics, University of St. Gallen.

Kanbur, R. (2000). Aid, conditionality and debt in Africa. European Economic Review, 32(9), 409-22. http://dx.doi.org/10.4324/9780203461761.ch18

Luan, C. (2016). Không được vay vốn ODA, có khi lại tốt cho Việt Nam. Pháp luạt. Retrieved from http://plo.vn/kinh-te/khong-duoc-vay-von-oda-co-khi-lai-tot-cho-viet-nam-619433.html

McMillan, L. (2011). Foreign Aid and Economic Development. School of Doctoral Studies European Union Journal, (3), 158-165.

Mosley, P. (1980). Aid, savings, and growth revisited. Oxford Bulletin of Economics and Statistics, 42(2), 79-96. http://dx.doi.org/10.1111/j.1468-0084.1980.mp42002002.x

Nelson, R. (1956). A theory of the low-level equilibrium trap in underdeveloped economies. American Economic Review, 46, 894-908.

Ngo Thang Loi. (2013). Kinh tế phát triển. Đại học kinh tế quốc dân.

Sachs Jeffrey. (2005). The End of Poverty: Economic Possibilities for Our Time. New York: Penguin.

Stiglitz, J. (2002, April 14). Overseas Aid is Money Well Spent. Financial Times, 3(5).

Vietnam General Statistics Office. (1990-2015). Niên giám thống kê Việt Nam - Statistical Yearbook of Vietnam. Nhà xuất bản Thống kê 1990-2015.

\section{Copyrights}

Copyright for this article is retained by the author(s), with first publication rights granted to the journal.

This is an open-access article distributed under the terms and conditions of the Creative Commons Attribution license (http://creativecommons.org/licenses/by/4.0/). 